\title{
Coordination Studies of Copper(II), Cobalt(II) and Iron(II) with Isomeric Pyridyl-Tetrazole Ligands
}

\author{
Fintan Kelleher \\ Technological University Dublin, fintan.kelleher@tudublin.ie \\ Andrew Bond \\ University of Southern Denmark, Odense \\ Adrienne Fleming \\ Technological University Dublin
}

See next page for additional authors

Follow this and additional works at: https://arrow.tudublin.ie/ittsciart

\section{Recommended Citation}

Kelleher, F., Bond, A., Fleming, A., Gaire, J., McKee, V., and Sheridan, U. Coordination studies of copper(II), cobalt(II) and iron(II) with isomeric pyridyl-tetrazole ligands. Polyhedron, Volume 33, Issue 1, 9 February 2012, Pages 289-296. http://dx.doi.org/10.1016/j.poly.2011.11.038,

This Article is brought to you for free and open access by the School of Science and Computing at ARROW@TU Dublin. It has been accepted for inclusion in Articles by an authorized administrator of ARROW@TU Dublin. For more information, please contact

arrow.admin@tudublin.ie, aisling.coyne@tudublin.ie, gerard.connolly@tudublin.ie.

Funder: Irish Government; NUI Maynooth; Danish Natural Sciences Research Council and the Carlsberg Foundation

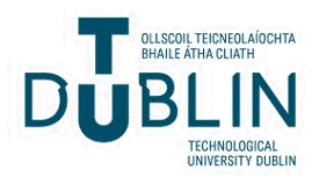




\section{Authors}

Fintan Kelleher, Andrew Bond, Adrienne Fleming, Jackie Gaire, John McGinley, Vickie McKee, and Ursula Sheridan 


\section{Coordination studies of copper(II), cobalt(II) and iron(II) with isomeric pyridyl- tetrazole ligands}

Andrew D. Bond, ${ }^{a}$ Adrienne Fleming, ${ }^{b}$ Jackie Gaire, ${ }^{b}$ Fintan Kelleher, ${ }^{b}$ John McGinley, ${ }^{*} c$ Vickie McKee $^{d}$ and Ursula Sheridan ${ }^{c}$

${ }^{a}$ Department of Physics and Chemistry, University of Southern Denmark, DK-5230 Odense M, Denmark.

${ }^{b}$ Molecular Design and Synthesis Group, Department of Science, Institute of Technology Tallaght, Dublin 24, Ireland.

${ }^{c}$ Department of Chemistry, National University of Ireland Maynooth, Maynooth, Co. Kildare, Ireland. Fax: +353 1708 3815; Tel: +3531708 4615; E-mail: john.mcginley@nuim.ie

${ }^{d}$ Department of Chemistry, Loughborough University, Loughborough, Leicestershire LE11 3TU, England. 


\begin{abstract}
The reaction of 2-(2H-tetrazol-5-yl)pyridine (L1) with 1,6-dibromohexane results in formation of the isomers 2-(6"-bromohexyl-(1-tetrazol-5-yl)pyridine (L2) and 2-(6"-bromohexyl-(2-tetrazol-5yl)pyridine ( $\mathbf{L 3})$. Coordination reactions of $\mathbf{L 2}$ and $\mathbf{L 3}$ with $\mathrm{CuCl}_{2} \cdot 2 \mathrm{H}_{2} \mathrm{O}, \mathrm{Co}(\mathrm{SCN})_{2}$ and $\mathrm{Fe}\left(\mathrm{ClO}_{4}\right)_{2} \cdot \mathrm{H}_{2} \mathrm{O}$ yielded the strongly coloured solids $\left[\mathrm{Cu}(\mathrm{III})(\mathbf{L 2}) \mathrm{Cl}_{2}\right]_{2}(\mathbf{1}),\left[\mathrm{Cu}(\mathrm{II})(\mathbf{L 3}) \mathrm{Cl}_{2}\right]_{2}(\mathbf{2})$, $\left[\mathrm{Co}(\mathrm{II})(\mathbf{L 2})_{2}(\mathrm{NCS})_{2}\right] \quad(\mathbf{3}), \quad\left[\mathrm{Co}(\mathrm{II})(\mathbf{L 3})_{2}(\mathrm{NCS})_{2}\right] \quad(\mathbf{4}), \quad\left[\mathrm{Fe}(\mathrm{II})(\mathbf{L 2})_{2}\left(\mathrm{H}_{2} \mathrm{O}\right)_{2}\right]\left(\mathrm{ClO}_{4}\right)_{2} \quad(\mathbf{5}) \quad$ and $\left[\mathrm{Fe}(\mathrm{II})(\mathbf{L 3})_{2}\left(\mathrm{H}_{2} \mathrm{O}\right)_{2}\right]\left(\mathrm{ClO}_{4}\right)_{2}$ (6), containing high-spin metal centres for the $\mathrm{Co}(\mathrm{II})$ and $\mathrm{Fe}(\mathrm{II})$ compounds. X-ray crystal structures were obtained for complexes 1-5. In each complex, ligands L2 and $\mathbf{L} \mathbf{3}$ coordinate to the metal centre through the pyridyl $\mathrm{N}$ atom and the $1-N$ site of the tetrazole ring, and the pyridyl-tetrazole ligand remains planar in all cases except $\mathbf{3}$. Complexes $\mathbf{1}$ and $\mathbf{2}$ comprise a central $\mathrm{Cu}_{2} \mathrm{Cl}_{2}$ dimeric core with $\mathrm{Cu}(\mathrm{II})$ in an essentially square-pyramidal coordination environment. Complexes 3 and $\mathbf{4}$ contain $\mathrm{Co}(\mathrm{II})$ in a distorted octahedral coordination environment. In $\mathbf{3}$, the pyridyl and tetrazole rings of $\mathbf{L} \mathbf{2}$ are twisted with respect to each other and the complex adopts a puckered conformation in its equatorial plane. Complex 5 contains water molecules coordinated to $\mathrm{Fe}(\mathrm{II})$ in the axial sites, which form hydrogen bonds to the perchlorate counter anions.
\end{abstract}




\section{Introduction}

A great deal of attention has been devoted toward the synthesis of functional compounds containing

polyazole rings, particularly tetrazoles and their derivatives, due to their practical applications. ${ }^{1-4}$ The development of "click" chemistry, as described by Sharpless and co-workers, ${ }^{5}$ has resulted in a recent increase in tetrazole structures. Tetrazole derivatives have found applications in therapeutics as antihypertensive agents, ${ }^{6}$ antibiotics, ${ }^{7}$ and drugs for AIDS treatment. ${ }^{8}$ They are also studied in the field of coordination chemistry. ${ }^{9}$ Both tetrazole and its derivatives, normally the 5 -substituted derivatives, can act as both di- and polydentate ligands exhibiting several coordination modes. ${ }^{10}$ Mono 1- and 2-substituted tetrazoles are often used for the construction of coordination networks. ${ }^{9,10}$ Our interest in tetrazoles concerns their use as precursors for the formation of new functionalized polytetrazole macromolecules, which have potential applications as sensors or in molecular recognition. We have previously reported the addition of pendant short-chain arms to various bis-tetrazoles, as well as the synthesis of several tetra-tetrazole macrocycles, including the first example of a host-guest interaction between a tetra-tetrazole macrocycle and a solvent molecule. ${ }^{11-16}$ To expand this area, we are investigating the use of tetrazole containing compounds as potential metal-based therapeutic agents, especially as anti-cancer or anti-fungicidal agents. In this paper, we describe the synthesis of some pyridyl-tetrazole compounds containing bromohexyl pendant arms (see Scheme 1) and examine their coordination chemistry with Fe(II), Co(II) and $\mathrm{Cu}$ (II) salts, which are a range of metal cations which the human body can tolerate. The biological studies of these complexes will be discussed in a future paper. ${ }^{17}$

\section{Results and Discussion}

\section{Ligand syntheses and characterisation}

Synthesis of 2-(2H-tetrazol-5-yl)pyridine (L1) and its subsequent reaction with 1,6-dibromoexane to give the isomers 2-(6"'-bromohexyl-(1-tetrazol-5-yl)pyridine (L2) and 2-(6',-bromohexyl-(2tetrazol-5-yl)pyridine (L3) was carried out as in a manner similar to that described in the literature, ${ }^{18}$ as shown in Scheme 1 . The reaction of sodium azide with 2-cyanopyridine in the presence of ammonium chloride and lithium chloride in dry dimethylformamide (DMF) yielded L1 as brown needles on recrystallisation from ethanol. The ${ }^{13} \mathrm{C} N \mathrm{NM}$ and IR spectra of the needles confirmed the presence of the tetrazole ring with a signal at $154.9 \mathrm{ppm}$ in the ${ }^{13} \mathrm{C} \mathrm{NMR}$ spectrum indicating the formation of a 1,5-disubstituted tetrazole and the absence of a signal at $2220 \mathrm{~cm}^{-1}$ in the IR spectrum due to an azide band. ${ }^{15,19,20}$ The ${ }^{1} \mathrm{H}$ NMR spectrum of $\mathbf{L 1}$, obtained in $\mathrm{CD}_{3} \mathrm{OD}$, 
showed the expected signals for the pyridine ring, while the $\mathrm{NH}$ proton on the tetrazole appeared as a broad signal at $3.9 \mathrm{ppm}$.

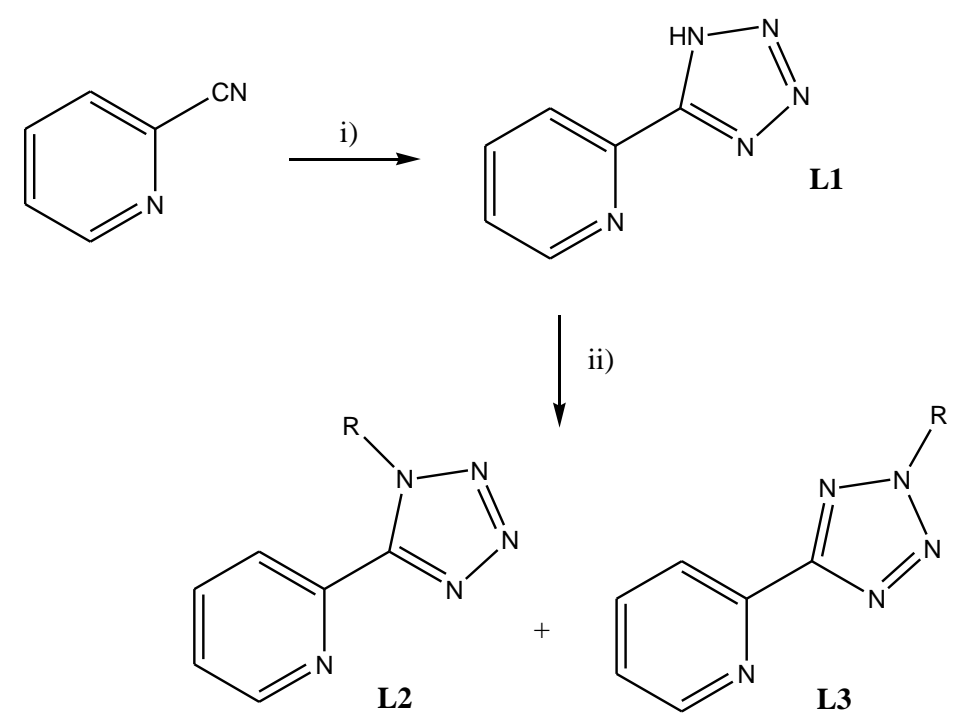

Scheme 1 Reaction conditions: i) $\mathrm{NaN}_{3}, \mathrm{LiCl}, \mathrm{NH}_{4} \mathrm{Cl}, \mathrm{DMF}, \Delta, 10 \mathrm{hr}$; ii) 1,6-dibromohexane, $\mathrm{K}_{2} \mathrm{CO}_{3}$, butanone, $\Delta, 24 \mathrm{hr} ; \mathrm{R}=\mathrm{C}_{6} \mathrm{H}_{12} \mathrm{Br}$.

The reaction of $\mathbf{L 1}$ with 1,6-dibromohexane in either 2-butanone or acetonitrile with potassium carbonate as base gave a mixture of products $\mathbf{L} \mathbf{2}$ and $\mathbf{L 3}$, arising from alkylation at either the 1-N or 2- $N$ positions. Column chromatography separated the products from the reactants. Both $\mathbf{L} 2$ and $\mathbf{L 3}$ are low melting, waxy solids. The isomers are readily distinguishable by their ${ }^{13} \mathrm{C}$ NMR spectra with the ${ }^{13} \mathrm{C}$ NMR chemical shift of the tetrazole $\mathrm{C}$ atom appearing at $c a .154 .0$ or $164.0 \mathrm{ppm}$ in the 1,5- and 2,5-disubstituted tetrazoles, respectively. ${ }^{15,19,20}$ In this case, the $1-N$ isomer (L2) gave a signal at $151.4 \mathrm{ppm}$, while the $2-N$ isomer (L3) gave a signal at $164.7 \mathrm{ppm}$. The ${ }^{1} \mathrm{H}$ NMR spectra of both $\mathbf{L} 2$ and $\mathbf{L 3}$ show four signals for the pyridyl protons, a triplet for methylene group beside the $\mathrm{Br}$ atom, a triplet for the methylene group beside the tetrazole and three other signals for the remaining methylene groups of the bromoalkyl chain. The signals for the methylene protons beside the tetrazole appear at 5.00 ppm for $\mathbf{L} 2$ and 4.73 ppm for $\mathbf{L 3}$.

\section{Coordination Reactions}

The transition-metal salts $\mathrm{CuCl}_{2} \cdot 2 \mathrm{H}_{2} \mathrm{O}, \mathrm{Co}(\mathrm{SCN})_{2}$ and $\mathrm{Fe}\left(\mathrm{ClO}_{4}\right)_{2} \cdot \mathrm{H}_{2} \mathrm{O}$ were reacted with $\mathbf{L} 2$ and $\mathbf{~} 3$, respectively, in methanol at reflux temperature under an inert atmosphere for two hours. All reactions were carried out using a 1:1 metal:ligand stoichiometry (see Schemes $2 \& 3$ ). The resulting strongly coloured solutions were allowed to stand for several days, after which time the 
solid products were filtered off. Elemental analyses on all of the products obtained showed that the $\mathrm{Cu}$ complexes (1 and 2) have a 1:1 metal:ligand composition while both the Co complexes (3 and 4) and the Fe complexes (5 and 6) had a 1:2 metal:ligand composition.

The $\mathrm{Cu}$ complexes 1 and 2 have magnetic moments of 2.6 and 3.2 B.M., respectively, which indicate the expected presence of $\mathrm{Cu}(\mathrm{II})$. Both Co complexes $\mathbf{3}$ and $\mathbf{4}$ have magnetic moments in the ranges of 4.5 and 3.65 B.M., which are consistent with the presence of high-spin $\mathrm{Co}(\mathrm{II})$. The magnetic moments for the Fe complexes 5 and $\mathbf{6}$ are 4.7 and 5.0 B.M., respectively, which indicate the presence of high-spin Fe(II). The observation of high-spin ions in the latter two cases is consistent with the findings of Henderson et al. who have reported several Mn complexes of $\mathbf{L} \mathbf{1}$ all contained high-spin $\mathrm{Mn}(\mathrm{II}){ }^{9 \mathrm{a}}$
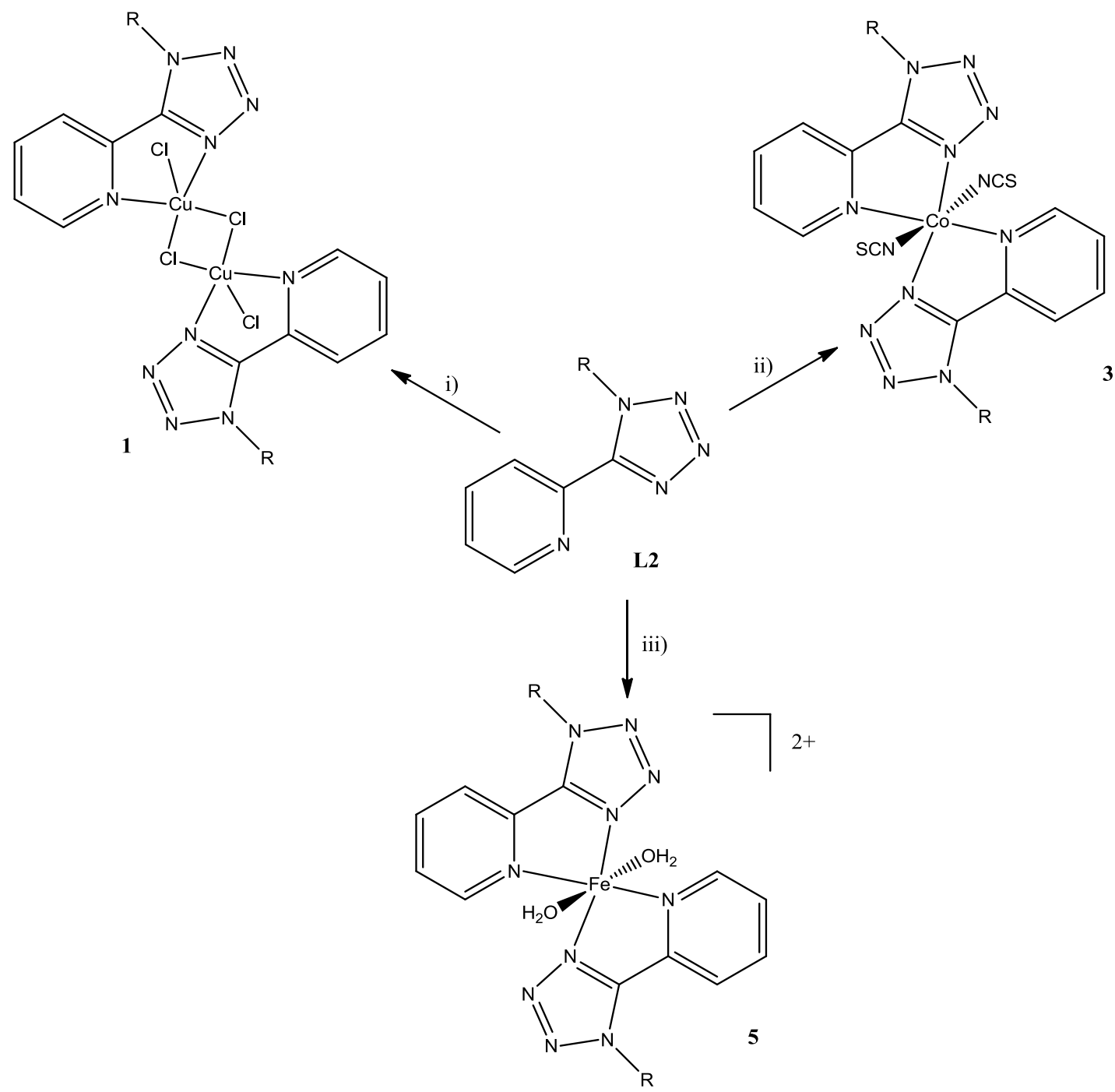

Scheme 2 Reaction conditions: i) $\mathrm{CuCl}_{2} .2 \mathrm{H}_{2} \mathrm{O}, \mathrm{MeOH}, \Delta, 2 \mathrm{hr}$; ii) $\mathrm{Co}(\mathrm{SCN})_{2}, \mathrm{MeOH}, \Delta, 2 \mathrm{hr}$; i) $\mathrm{Fe}\left(\mathrm{ClO}_{4}\right)_{2} \cdot \mathrm{xH}_{2} \mathrm{O}, \mathrm{MeOH}, \Delta, 2 \mathrm{hr}$. 

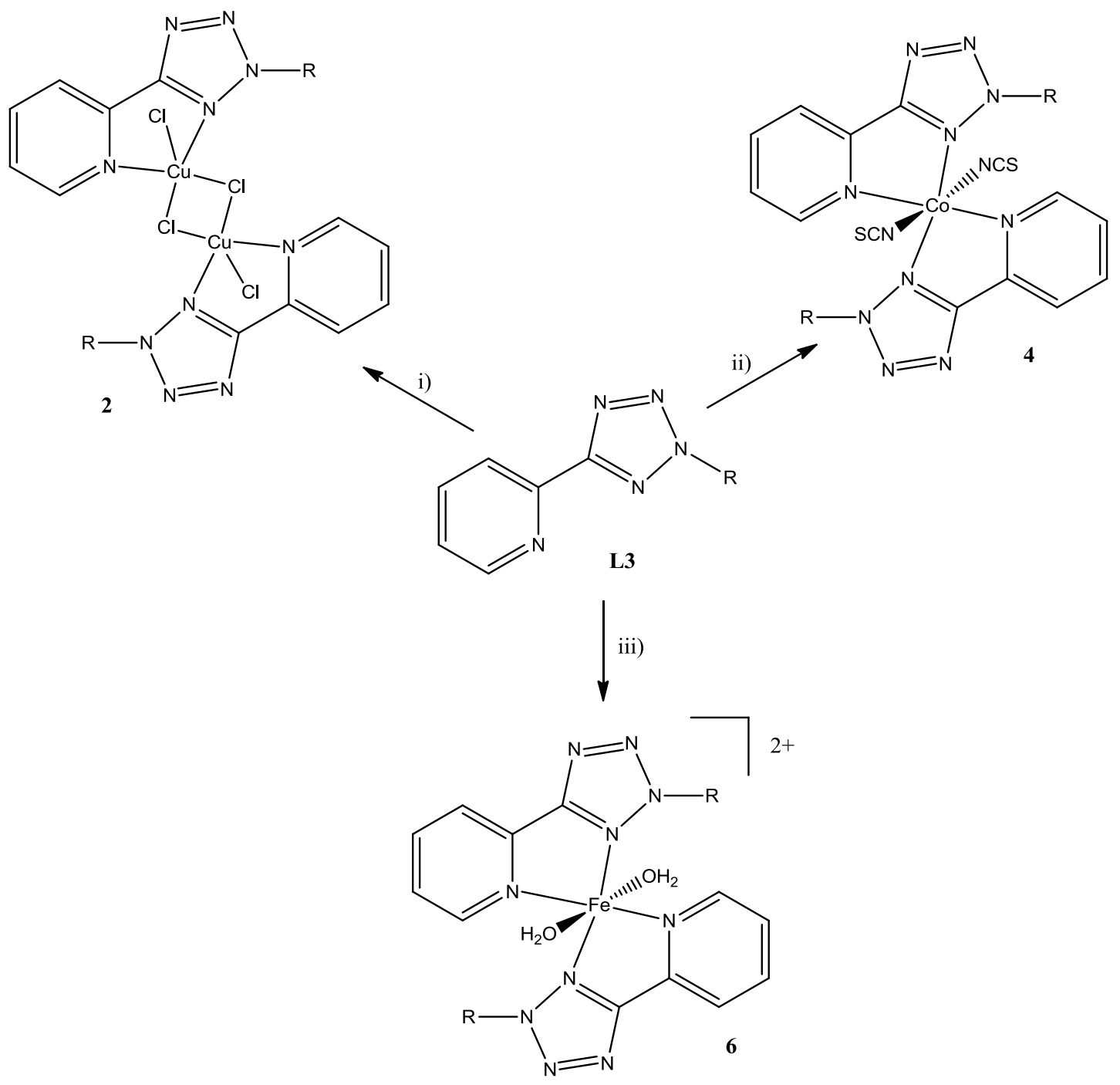

Scheme 3 Reaction conditions: i) $\mathrm{CuCl}_{2} \cdot 2 \mathrm{H}_{2} \mathrm{O}, \mathrm{MeOH}, \Delta, 2 \mathrm{hr}$; ii) $\mathrm{Co}(\mathrm{SCN})_{2}, \mathrm{MeOH}, \Delta, 2 \mathrm{hr}$; i) $\mathrm{Fe}\left(\mathrm{ClO}_{4}\right)_{2} \cdot \mathrm{xH}_{2} \mathrm{O}, \mathrm{MeOH}, \Delta, 2 \mathrm{hr}$.

Crystal structures of the $C u(I I)$ complexes $\mathbf{1}$ and $\mathbf{2}$

Dark green crystals of $\mathbf{1}$ and $\mathbf{2}$ suitable for X-ray diffraction were obtained from methanol and ethanol solutions of $\mathrm{CuCl}_{2} \cdot \mathrm{H}_{2} \mathrm{O}$ with $\mathbf{~} 2$ and $\mathbf{~} \mathbf{3}$, respectively. Crystallographic data for all structures are presented in Table 1 . Both 3 and 7 consist of dichloro-bridged dimeric $\{\mathrm{Cu}(\mathrm{II})(\mu-$ $\mathrm{Cl}) \mathrm{Cl}\}_{2}$ units, with the coordination sphere about each $\mathrm{Cu}(\mathrm{II})$ atom comprising one pyridine $\mathrm{N}$ atom, one tetrazole $\mathrm{N}$ atom and three $\mathrm{Cl}$ atoms (Figs. 1 and 2). Selected bond distances and angles are listed in Tables 2 and 3, respectively. In 1, the complex lies on a crystallographic inversion centre, while in $\mathbf{2}$, the bromohexyl chains adopt different conformations with respect to the central core of the complex. One of the hexyl chains in $\mathbf{2}$ is disordered (Fig. 2). 


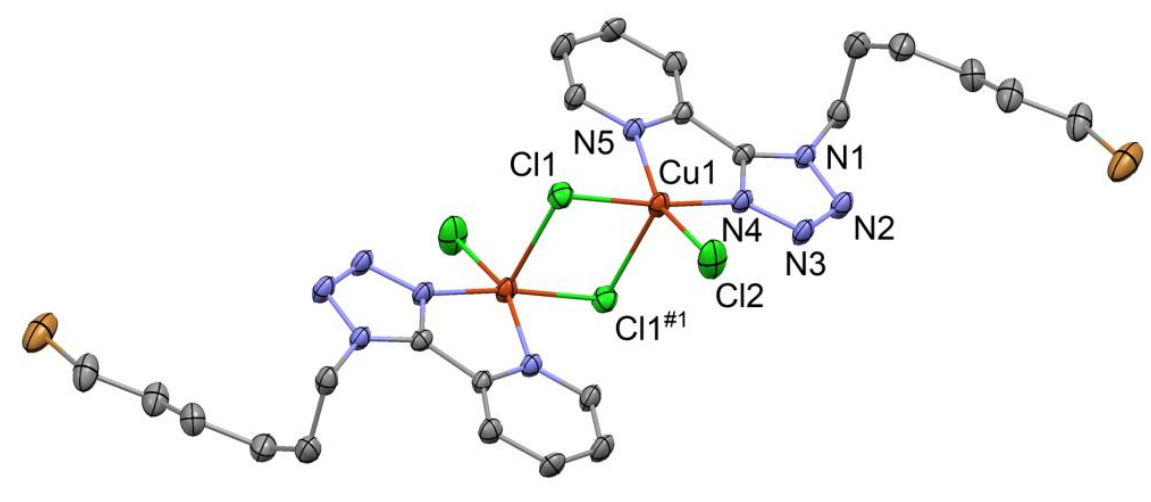

Fig. 1 Molecular structure of 1 with displacement ellipsoids at the 50\% probability level ( $\mathrm{H}$ atoms omitted). The complex lies on a crystallographic inversion centre.

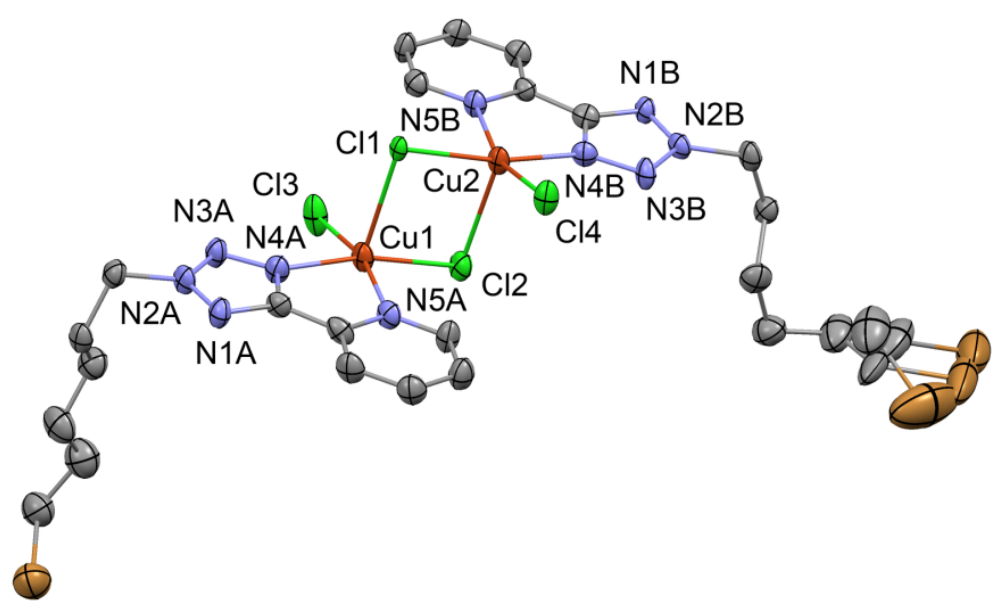

Fig. 2 Molecular structure of 2 with displacement ellipsoids at the 50\% probability level (H atoms omitted). One bromohexyl pendant arm is modelled as disordered over three orientations. 
Table 1 Crystallographic Data for 1- 5.

1

Formula

$M / \mathrm{g} \mathrm{mol}^{-1}$

Crystal system

Space group

$T / \mathrm{K}$

$a / \AA$

b/Å

$c / \AA ̊$

$\alpha /{ }^{\circ}$

$\beta /{ }^{\circ}$

$\gamma /{ }^{\circ}$

$V / \AA^{3}$

$Z$

$D_{c} / \mathrm{g} \mathrm{cm}^{-3}$

Reflections collected

Unique reflections

$R_{\text {int }}$

Observed reflections

$[I>2 \sigma(I)]$

No. parameters

No. restraints

$R 1[I>2 \sigma(I)]$

$w R 2$ (all data)

$\mathrm{GOF}$

\section{$\mathrm{C}_{24} \mathrm{H}_{32} \mathrm{Br}_{2} \mathrm{Cl}_{4} \mathrm{Cu}_{2} \mathrm{~N}_{10}$}

889.30

Triclinic

$P$-1

180(2)

9.2946(5)

$9.4441(7)$

10.6132(7)

$76.945(2)$

$80.052(2)$

$66.114(2)$

$826.35(9)$

1

1.787

14734

2897

0.026

2632

190

0

0.0264

0.074

1.09
2

$\mathrm{C}_{24} \mathrm{H}_{32} \mathrm{Br}_{2} \mathrm{Cl}_{4} \mathrm{Cu}_{2} \mathrm{~N}_{10} \quad \mathrm{C}_{26} \mathrm{H}_{32} \mathrm{Br}_{2} \mathrm{CoN}_{12} \mathrm{~S}_{2}$ 889.30

Triclinic

$P-1$

$150(2)$

9.5645(17)

$12.213(2)$

$14.688(3)$

92.214(3)

$107.256(2)$

93.937(2)

1631.5(5)

2

1.810

13771

6383

0.050

3783

415

147

0.066

0.217

1.03
3

795.51

Triclinic

$P-1$

120(2)

8.7827(4)

12.1112(6)

16.0963(6)

83.204(2)

83.219(2)

74.195(2)

1629.23(13)

2

1.622

32290

6043

0.033

4855

398

0

0.041

0.108

1.04
4

$\mathrm{C}_{26} \mathrm{H}_{32} \mathrm{Br}_{2} \mathrm{CoN}_{12} \mathrm{~S}_{2}$

795.51

Triclinic

$P-1$

150(2)

8.2324(15)

12.863(2)

15.951(3)

99.917(3)

93.901(3)

90.270(3)

1659.8(5)

2

1.592

12805

5600

0.067

2764

426

468

0.081

0.252

1.05
5

$\mathrm{C}_{24} \mathrm{H}_{36} \mathrm{Br}_{2} \mathrm{Cl}_{2} \mathrm{FeN}_{10} \mathrm{O}_{10}$

911.20

Monoclinic

$P 2{ }_{1} / c$

150(2)

9.8682(11)

11.7061(12)

15.2784(16)

90

92.999(2)

90

1762.5(3)

2

1.717

14802

3463

0.041

2565

319

218

0.047

0.115

1.05 
The geometry of the central core is closely comparable in $\mathbf{1}$ and 2: the 28 non- $\mathrm{H}$ atoms in each complex (excluding the bromohexyl chains) can be overlaid with an rms deviation of $0.13 \AA$. The coordination geometry of each $\mathrm{Cu}$ (II) centre is distorted square pyramidal. The Addison parameter, $t$, is 0.19 for $\mathbf{1}$, compared to 0.05 for $\mathrm{Cu}(1)$ and 0.12 for $\mathrm{Cu}(2)$, respectively, in 2 (where $t=0$ for ideal square-pyramidal and $t=1$ for ideal trigonal-bipyramidal). ${ }^{21}$ Each pyridyl-tetrazole ligand binds to the $\mathrm{Cu}(\mathrm{II})$ atom through one tetrazole $\mathrm{N}$ atom at the $1-N$ site of the tetrazole ring and through the pyridyl $\mathrm{N}$ atom, to generate a five-membered chelate ring. The tetrazole ring is coplanar with the pyridyl ring. This coplanarity has been seen in other metal complexes containing pyridyltetrazole ligands. ${ }^{9,10}$ In the central core, the four-membered $\mathrm{Cu}_{2} \mathrm{Cl}_{2}$ rings are planar in both cases, and the $\mathrm{Cu}(\mathrm{II})-\mathrm{Cl}$ bond distances are comparable to those of other dichloro-bridged dimers in the literature. $^{22}$ The $\mathrm{Cu}-\mathrm{Cl}$ (apical) bond distances are longer than the $\mathrm{Cu}-\mathrm{Cl}$ (equatorial) bond distances by ca $0.35 \AA$ (Table 2).

Table 2 Selected bond lengths $(\AA)$ and angles $\left({ }^{\circ}\right)$ for $\mathbf{1}$

$\begin{array}{lcll}\mathrm{Cu}(1)-\mathrm{Cl}(1) & 2.2553(7) & \mathrm{Cu}(1)-\mathrm{N}(4) & 1.987(2) \\ \mathrm{Cu}(1)-\mathrm{Cl}(1)^{\mp 1} & 2.6392(8) & \mathrm{Cu}(1)-\mathrm{N}(5) & 2.088(2) \\ \mathrm{Cu}(1)-\mathrm{Cl}(2) & 2.2257(8) & & \\ & & & \\ \mathrm{Cl}(1)-\mathrm{Cu}(1)-\mathrm{Cl}(2) & 94.32(3) & \mathrm{N}(4)-\mathrm{Cu}(1)-\mathrm{Cl}(1) & 172.29(7) \\ \mathrm{Cu}(1)-\mathrm{Cl}(1)-\mathrm{Cu}(1)^{\mp 1} & 89.97(2) & \mathrm{N}(4)-\mathrm{Cu}(1)-\mathrm{Cl}(2) & 92.38(7) \\ \mathrm{Cl}(2)-\mathrm{Cu}(1)-\mathrm{Cl}(1)^{\# 1} & 106.12(3) & \mathrm{N}(4)-\mathrm{Cu}(1)-\mathrm{Cl}(1)^{\# 1} & 91.82(7) \\ \mathrm{N}(5)-\mathrm{Cu}(1)-\mathrm{Cl}(1) & 94.28(6) & \mathrm{N}(4)-\mathrm{Cu}(1)-\mathrm{N}(5) & 78.19(9) \\ \mathrm{N}(5)-\mathrm{Cu}(1)-\mathrm{Cl}(2) & 160.64(7) & \mathrm{Cl}(1)-\mathrm{Cu}(1)-\mathrm{Cl}(1)^{\# 1} & 90.03(2) \\ \mathrm{N}(5)-\mathrm{Cu}(1)-\mathrm{Cl}(1) \# 1 & 91.20(6) & & \end{array}$

Symmetry code \#1: $2-x,-y,-z$

In $\mathbf{1}$, the two bromohexyl arms orient themselves above and below the central $\mathrm{Cu}_{2} \mathrm{Cl}_{2}$ core, pointing away from each other in a centrosymmetric arrangement (Fig. 1), whereas in 2, both arms point in the same direction (Fig. 2). This difference in orientation is probably attributable to packing effects. In 1, the complexes are arranged into well-defined layers, with the pyridyl ring of one L2 ligand approaching the tetrazole ring of an adjacent $\mathbf{L 2}$ ligand in a side-on co-planar fashion, making C$\mathrm{H} \cdots \mathrm{N}$ contacts (see Figures in $\mathrm{ESI}^{\dagger}$ ). The bromohexyl arms form an interdigitated arrangement between those layers, with adjacent arms lying parallel to each other in a manner typical of closepacked alkyl chains. In 2, the comparable side-on approach of $\mathbf{L 3}$ ligands is blocked by the presence of the bromohexyl arm, and the complexes instead adopt a bilayer type arrangement, where the pyridyl ring of one $\mathbf{L 3}$ ligand approaches the $\mathrm{Cl}$ atoms of an adjacent complex, making $\mathrm{C}-\mathrm{H} \cdots \mathrm{Cl}$ 
contacts. In this arrangement, the bromohexyl pendant arms are forced to lie on the same side of the complex, where they form a less well-defined packing pattern between the bilayers.

Table 3 Selected bond lengths $(\AA)$ and angles $\left(^{\circ}\right)$ for 2

$\begin{array}{lclc}\mathrm{Cu}(1)-\mathrm{Cl}(3) & 2.235(2) & \mathrm{Cu}(2)-\mathrm{Cl}(4) & 2.229(2) \\ \mathrm{Cu}(1)-\mathrm{Cl}(1) & 2.716(2) & \mathrm{Cu}(2)-\mathrm{Cl}(2) & 2.671(2) \\ \mathrm{Cu}(1)-\mathrm{Cl}(2) & 2.2637(19) & \mathrm{Cu}(2)-\mathrm{Cl}(1) & 2.3178(18) \\ \mathrm{Cu}(1)-\mathrm{N}(4 \mathrm{~A}) & 2.012(6) & \mathrm{Cu}(2)-\mathrm{N}(4 \mathrm{~B}) & 2.013(6) \\ \mathrm{Cu}(1)-\mathrm{N}(5 \mathrm{~A}) & 2.085(6) & \mathrm{Cu}(2)-\mathrm{N}(5 \mathrm{~B}) & 2.090(6) \\ & & & \\ \mathrm{Cl}(3)-\mathrm{Cu}(1)-\mathrm{Cl}(2) & 93.87(8) & \mathrm{Cl}(4)-\mathrm{Cu}(2)-\mathrm{Cl}(1) & 94.10(7) \\ \mathrm{Cl}(2)-\mathrm{Cu}(1)-\mathrm{Cl}(1) & 92.36(7) & \mathrm{Cl}(1)-\mathrm{Cu}(2)-\mathrm{Cl}(2) & 92.30(7) \\ \mathrm{Cl}(3)-\mathrm{Cu}(1)-\mathrm{Cl}(1) & 101.41(8) & \mathrm{Cl}(4)-\mathrm{Cu}(2)-\mathrm{Cl}(2) & 104.93(8) \\ \mathrm{N}(4 \mathrm{~A})-\mathrm{Cu}(1)-\mathrm{Cl}(3) & 91.79(19) & \mathrm{N}(4 \mathrm{~B})-\mathrm{Cu}(2)-\mathrm{Cl}(4) & 90.89(18) \\ \mathrm{N}(4 \mathrm{~A})-\mathrm{Cu}(1)-\mathrm{Cl}(2) & 167.9(2) & \mathrm{N}(4 \mathrm{~B})-\mathrm{Cu}(2)-\mathrm{Cl}(1) & 169.71(19) \\ \mathrm{N}(4 \mathrm{~A})-\mathrm{Cu}(1)-\mathrm{Cl}(1) & 97.0(2) & \mathrm{N}(4 \mathrm{~B})-\mathrm{Cu}(2)-\mathrm{Cl}(2) & 95.09(19) \\ \mathrm{N}(4 \mathrm{~A})-\mathrm{Cu}(1)-\mathrm{N}(5 \mathrm{~A}) & 78.5(2) & \mathrm{N}(4 \mathrm{~B})-\mathrm{Cu}(2)-\mathrm{N}(5 \mathrm{~B}) & 78.5(2) \\ \mathrm{N}(5 \mathrm{~A})-\mathrm{Cu}(1)-\mathrm{Cl}(1) & 91.24(19) & \mathrm{N}(5 \mathrm{~B})-\mathrm{Cu}(2)-\mathrm{Cl}(1) & 94.41(17) \\ \mathrm{N}(5 \mathrm{~A})-\mathrm{Cu}(1)-\mathrm{Cl}(2) & 93.66(18) & \mathrm{N}(5 \mathrm{~B})-\mathrm{Cu}(2)-\mathrm{Cl}(2) & 90.10(19) \\ \mathrm{N}(5 \mathrm{~A})-\mathrm{Cu}(1)-\mathrm{Cl}(3) & 165.0(2) & \mathrm{N}(5 \mathrm{~B})-\mathrm{Cu}(2)-\mathrm{Cl}(4) & 162.39(19) \\ \mathrm{Cu}(2)-\mathrm{Cl}(1)-\mathrm{Cu}(1) & 86.57(6) & \mathrm{Cu}(1)-\mathrm{Cl}(2)-\mathrm{Cu}(2) & 88.75(7)\end{array}$

Crystal structures of the Co(II) complexes $\mathbf{3}$ and $\mathbf{4}$

Rust-coloured crystals of $\mathbf{3}$ were obtained from a methanol solution while green crystals of $\mathbf{4}$ were recrystallised from ethanol. Complex $\mathbf{3}$ contains one independent molecule lying on a crystallographic inversion centre, while $\mathbf{4}$ contains two independent complexes, lying on distinct crystallographic inversion centres. Selected bond distances and angles for $\mathbf{3}$ and $\mathbf{4}$ are listed in Tables 4 and 5, respectively. 


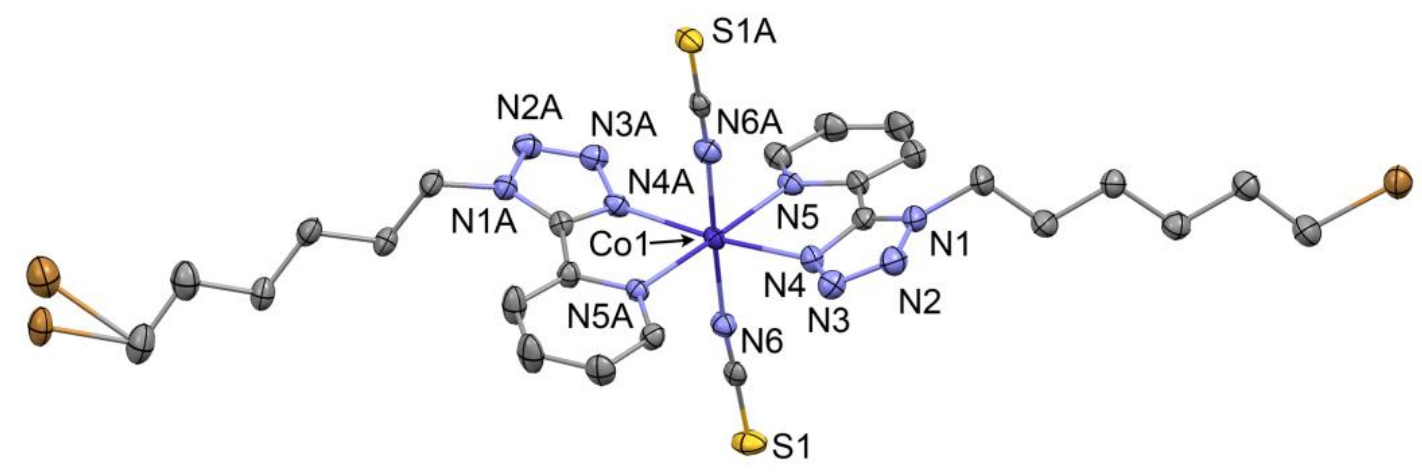

Fig. 3 Molecular structure of $\mathbf{3}$ with displacement ellipsoids at the 50\% probability level (H atoms omitted). One bromohexyl pendant arm displays disorder.

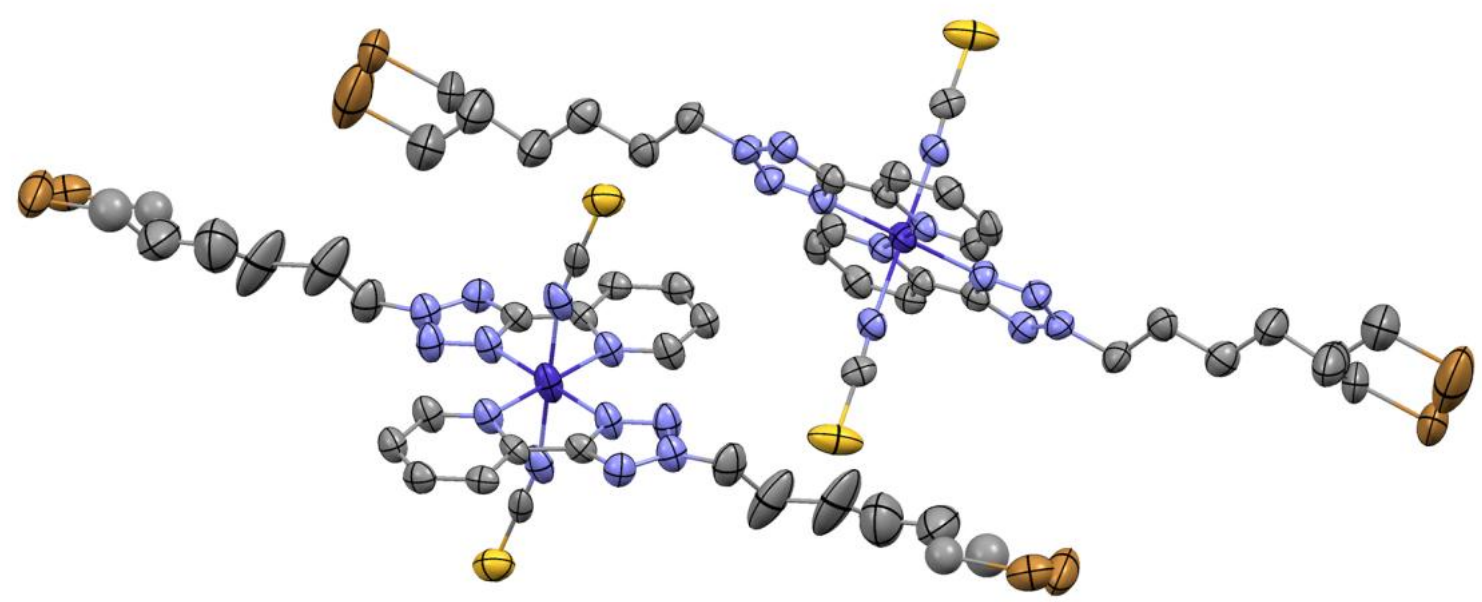

Fig. 4 Molecular structure of $\mathbf{4}$ with displacement ellipsoids at the $50 \%$ probability level (H atoms omitted). Two independent complexes lie on crystallographic inversion centres. Both display disorder of the bromohexyl pendant arms.

Table 4 Selected bond lengths $(\AA)$ and angles $\left(^{\circ}\right)$ for $\mathbf{3}$

$\begin{array}{lclr}\mathrm{Co}(1)-\mathrm{N}(4) & 2.142(3) & \mathrm{Co}(1)-\mathrm{N}(4 \mathrm{~A}) & 2.122(3) \\ \mathrm{Co}(1)-\mathrm{N}(5) & 2.139(3) & \mathrm{Co}(1)-\mathrm{N}(5 \mathrm{~A}) & 2.144(3) \\ \mathrm{Co}(1)-\mathrm{N}(6) & 2.039(3) & \mathrm{Co}(1)-\mathrm{N}(6 \mathrm{~A}) & 2.082(3) \\ & & & \\ \mathrm{N}(6)-\mathrm{Co}(1)-\mathrm{N}(6 \mathrm{~A}) & 178.22(13) & \mathrm{N}(6)-\mathrm{Co}(1)-\mathrm{N}(4 \mathrm{~A}) & 94.33(12) \\ \mathrm{N}(6 \mathrm{~A})-\mathrm{Co}(1)-\mathrm{N}(4 \mathrm{~A}) & 87.44(12) & \mathrm{N}(6)-\mathrm{Co}(1)-\mathrm{N}(5) & 90.03(12) \\ \mathrm{N}(6 \mathrm{~A})-\mathrm{Co}(1)-\mathrm{N}(5) & 89.80(12) & \mathrm{N}(4 \mathrm{~A})-\mathrm{Co}(1)-\mathrm{N}(5) & 103.13(12)\end{array}$




$\begin{array}{lclc}\mathrm{N}(6)-\mathrm{Co}(1)-\mathrm{N}(4) & 93.09(12) & \mathrm{N}(6 \mathrm{~A})-\mathrm{Co}(1)-\mathrm{N}(4) & 85.14(12) \\ \mathrm{N}(4 \mathrm{~A})-\mathrm{Co}(1)-\mathrm{N}(4) & 172.57(12) & \mathrm{N}(5)-\mathrm{Co}(1)-\mathrm{N}(4) & 76.56(12) \\ \mathrm{N}(6)-\mathrm{Co}(1)-\mathrm{N}(5 \mathrm{~A}) & 91.55(12) & \mathrm{N}(6 \mathrm{~A})-\mathrm{Co}(1)-\mathrm{N}(5 \mathrm{~A}) & 88.62(12) \\ \mathrm{N}(4 \mathrm{~A})-\mathrm{Co}(1)-\mathrm{N}(5 \mathrm{~A}) & 76.73(11) & \mathrm{N}(5)-\mathrm{Co}(1)-\mathrm{N}(5 \mathrm{~A}) & 178.41(12) \\ \mathrm{N}(4)-\mathrm{Co}(1)-\mathrm{N}(5 \mathrm{~A}) & 103.37(11) & & \end{array}$

Table 5 Selected bond lengths $(\AA)$ and angles $\left({ }^{\circ}\right)$ for 4

$\begin{array}{lcll}\mathrm{Co}(1 \mathrm{~A})-\mathrm{N}(6 \mathrm{~A}) & 2.080(7) & \mathrm{Co}(1 \mathrm{~B})-\mathrm{N}(6 \mathrm{~B}) & 2.061(9) \\ \mathrm{Co}(1 \mathrm{~A})-\mathrm{N}(4 \mathrm{~A}) & 2.142(6) & \mathrm{Co}(1 \mathrm{~B})-\mathrm{N}(4 \mathrm{~B}) & 2.137(7) \\ \mathrm{Co}(1 \mathrm{~A})-\mathrm{N}(5 \mathrm{~A}) & 2.158(6) & \mathrm{Co}(1 \mathrm{~B})-\mathrm{N}(5 \mathrm{~B}) & 2.156(6) \\ & & & \\ \mathrm{N}(6 \mathrm{~A})-\mathrm{Co}(1 \mathrm{~A})-\mathrm{N}(4 \mathrm{~A}) & 92.4(3) & \mathrm{N}(6 \mathrm{~B})-\mathrm{Co}(1 \mathrm{~B})-\mathrm{N}(4 \mathrm{~B}) & 88.6(3) \\ \mathrm{N}(6 \mathrm{~A})^{\# 1}-\mathrm{Co}(1 \mathrm{~A})-\mathrm{N}(4 \mathrm{~A}) & 87.6(3) & \mathrm{N}(6 \mathrm{~B})-\mathrm{Co}(1 \mathrm{~B})-\mathrm{N}(4 \mathrm{~B})^{\# L} & 91.4(3) \\ \mathrm{N}(6 \mathrm{~A})-\mathrm{Co}(1 \mathrm{~A})-\mathrm{N}(5 \mathrm{~A}) & 92.1(2) & \mathrm{N}(6 \mathrm{~B})^{\# L}-\mathrm{Co}(1 \mathrm{~B})-\mathrm{N}(5 \mathrm{~B}) & 87.4(3) \\ \mathrm{N}(6 \mathrm{~A})-\mathrm{Co}(1 \mathrm{~A})-\mathrm{N}(5 \mathrm{~A})^{\# 1} & 87.9(2) & \mathrm{N}(6 \mathrm{~B})-\mathrm{Co}(1 \mathrm{~B})-\mathrm{N}(5 \mathrm{~B}) & 92.6(3) \\ \mathrm{N}(4 \mathrm{~A})-\mathrm{Co}(1 \mathrm{~A})-\mathrm{N}(5 \mathrm{~A}) & 76.7(2) & \mathrm{N}(4 \mathrm{~B})^{\# L}-\mathrm{Co}(1 \mathrm{~B})-\mathrm{N}(5 \mathrm{~B}) & 102.8(2) \\ \mathrm{N}(4 \mathrm{~A})-\mathrm{Co}(1 \mathrm{~A})-\mathrm{N}(5 \mathrm{~A})^{\# 1} & 103.3(2) & \mathrm{N}(4 \mathrm{~B})-\mathrm{Co}(1 \mathrm{~B})-\mathrm{N}(5 \mathrm{~B})^{\# L} & 77.2(2)\end{array}$

Symmetry code $\# 1:-x,-y,-z, \# 2: 1-x,-y, 1-z$.

In both 3 and 4, $\mathrm{Co}$ (II) exhibits an octahedral coordination geometry with the equatorial plane consisting of two pyridyl-tetrazole ligands and the thiocyanate ligands in the axial positions. Again, each pyridyl-tetrazole ligand chelates to $\mathrm{Co}$ (II) through one tetrazole $\mathrm{N}$ atom at the $1-N$ site and through the pyridyl $\mathrm{N}$ atom. As for $\mathbf{1}$ and $\mathbf{2}$, the tetrazole rings are coplanar with the pyridine rings in $\mathbf{4}$, and the two pyridyl-tetrazole ligands within the complex are also approximately co-planar with each other. In $\mathbf{3}$, however, there is a significant twist within the ligand so that the planes of the tetrazole and pyridine rings form dihedral angles of $8.9(1)$ and $16.2(1)^{\circ}$ in the two independent ligands, and the complex as a whole displays a much more puckered geometry (Fig. 3), reminiscent of the saddle conformation frequently observed in porphyrin complexes. Again, this appears to driven by packing effects. The complexes lie in layers where the equatorial planes of the complexes are all essentially parallel (as opposed to edge-to-face type contacts observed in 4) (Fig. 5). At one side of the complex, the pyridyl-tetrazole ligands with the smaller degree of twist meet in centrosymmetric face-to-face type contacts. At the other side of the complex, a bromohexyl chain lies across the face of an adjacent complex, and the tetrazole ring of the ligand is twisted away from that chain, giving rise to the larger twist within the ligand. The twist also introduces relatively short $\mathrm{N}$...S contacts to a neighbouring thiocyanate ligand (3.325(4) $\AA$ ). 


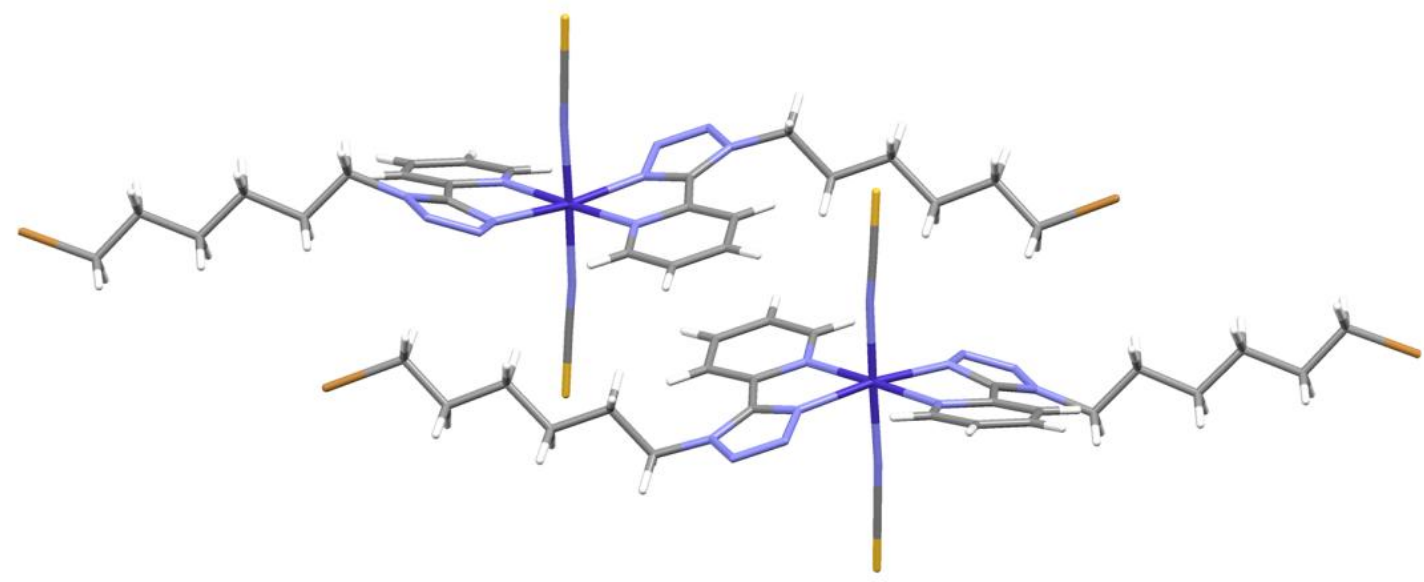

Fig. 5 Neighbouring complexes in the crystal structure of 3. In the centre, the face-to-face interaction between pyridyl-tetrazole ligands with the smaller degree of twist is visible. On the left and right sides, the tetrazole rings are twisted away from the planes of the pyridyl rings in order to accommodate the neighbouring bromohexyl chains.

\section{X-Ray Analysis of the Fe(II) complex of $\mathbf{L} 2$}

Brown crystals of $\mathbf{5}$ were obtained from the reaction between $\mathrm{Fe}\left(\mathrm{ClO}_{4}\right)_{2} \cdot \mathrm{H}_{2} \mathrm{O}$ and $\mathbf{~} \mathbf{2}$. Selected bond lengths and angles for $\mathbf{5}$ are given in Table 6. The complex lies on a crystallographic inversion centre and the bromoalkyl chain is modelled as disordered over two sets of positions (Fig. 6). The $\mathrm{Fe}(\mathrm{II})$ centre adopts a slightly distorted octahedral coordination geometry with the pyridyl-tetrazole ligands occupying the equatorial plane and water molecules occupying the axial positions. As for $\mathbf{1}$, 2 and 4, the tetrazole ring is coplanar with the pyridine ring. The complexes lie in layers with the perchlorate counter anions (modelled as disordered) between layers accepting hydrogen bonds from the coordinated water molecules. 


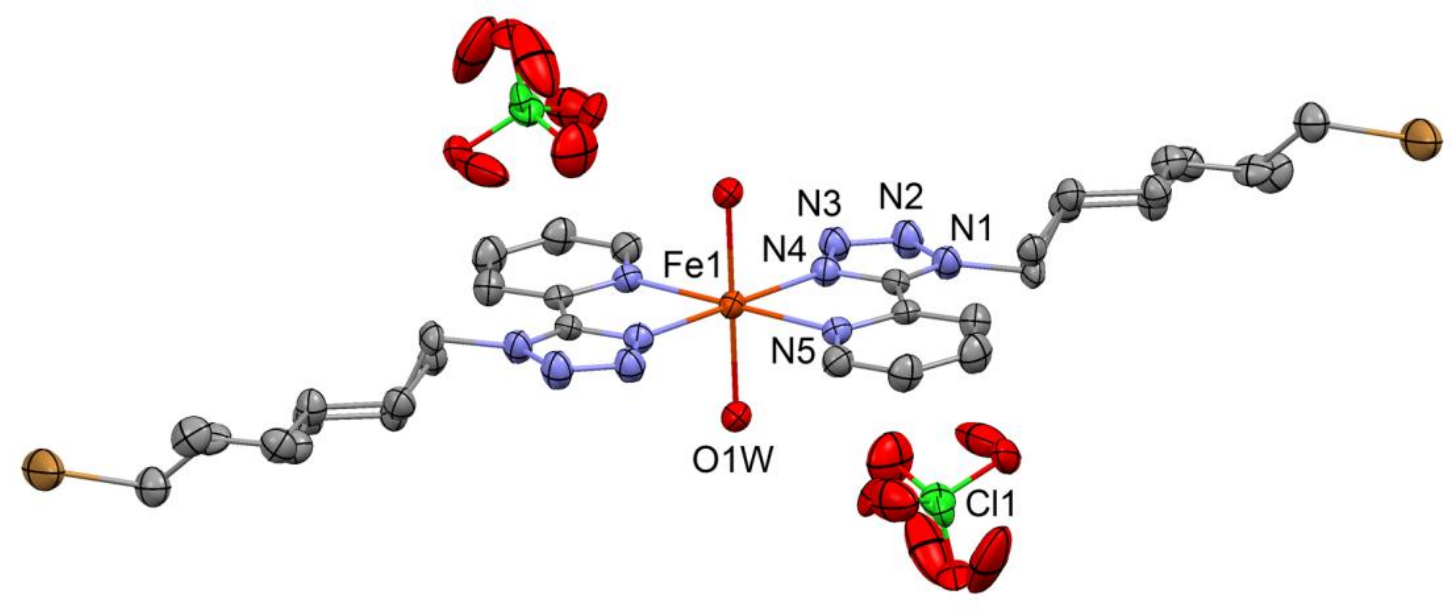

Fig. 6 Molecular structure of $\mathbf{5}$ with displacement ellipsoids at the $50 \%$ probability level (H atoms omitted). The complex lies on a crystallographic inversion centre. The bromohexyl chains and the perchlorate anions are modelled as disordered.

Table 6 Selected bond lengths $(\AA)$ and angles $\left({ }^{\circ}\right)$ for 5

$\begin{array}{lclc}\mathrm{Fe}(1)-\mathrm{O}(1 \mathrm{~W}) & 2.122(3) & \mathrm{Fe}(1)-\mathrm{N}(5) & 2.198(3) \\ \mathrm{Fe}(1)-\mathrm{N}(4) & 2.141(3) & \mathrm{C}(12)-\mathrm{Br}(1) & 1.947(4) \\ & & & \\ \mathrm{O}(1 \mathrm{~W})-\mathrm{Fe}(1)-\mathrm{N}(4) & 88.10(11) & \mathrm{O}(1 \mathrm{~W})-\mathrm{Fe}(1)-\mathrm{N}(4)^{\mp 1} & 91.90(11) \\ \mathrm{O}(1 \mathrm{~W})^{\# 1}-\mathrm{Fe}(1)-\mathrm{N}(5) & 89.46(10) & \mathrm{O}(1 \mathrm{~W})-\mathrm{Fe}(1)-\mathrm{N}(5) & 90.54(10) \\ \mathrm{N}(4)-\mathrm{Fe}-\mathrm{N}(5) & 75.03(11) & \mathrm{N}(4)^{\# 1}-\mathrm{Fe}(1)-\mathrm{N}(5) & 104.97(11)\end{array}$

\section{Experimental}

${ }^{1} \mathrm{H}$ and ${ }^{13} \mathrm{C}$ NMR ( $\delta$ ppm; $J$ Hz) spectra were recorded on a JEOL JNM-LA300 FT-NMR spectrometer using saturated $\mathrm{CDCl}_{3}$ solutions with $\mathrm{Me}_{4} \mathrm{Si}$ reference, unless indicated otherwise, with resolutions of $0.18 \mathrm{~Hz}$ and $0.01 \mathrm{ppm}$, respectively. Infrared spectra $\left(\mathrm{cm}^{-1}\right)$ were recorded as $\mathrm{KBr}$ discs or liquid films between $\mathrm{KBr}$ plates using either a Nicolet Impact 410 FT-IR spectrometer. Melting point analyses were carried out using a Stewart Scientific SMP 1 melting point apparatus and are uncorrected. Mass spectra were carried out in the Mass Spectrometry unit in the Centre for Synthesis and Chemical Biology, University College, Dublin. Magnetic susceptibility measurements were carried out at room temperature using a Johnson Matthey Magnetic Susceptibility Balance with $\left[\mathrm{HgCo}(\mathrm{SCN})_{4}\right]$ as reference. Microanalyses were carried out at the Microanalytical Laboratory of University College, Dublin. Standard Schlenk techniques were used throughout. Starting materials were commercially obtained and used without further purification. 
Caution! Nitrogen-rich compounds such as tetrazole derivatives are used as components for explosive mixtures. ${ }^{I}$ In our laboratory, the reactions described were run on a few gram scale, and no problems were encountered. However, great caution should be exercised when heating or handling compounds of this type. Caution! Although not encountered in our experiments, perchlorate salts of metal ions are potentially explosive and should be manipulated with care and used only in small quantities.

Synthesis of 2-(2H-tetrazol-5-yl)pyridine (L1)

A suspension of 2-cyanopyridine (4.14 g, $40 \mathrm{mmol})$, sodium azide (5.72 g, $88 \mathrm{mmol})$, ammonium chloride (4.70 g, $88 \mathrm{mmol})$ and lithium chloride $(1.20 \mathrm{~g}, 28 \mathrm{mmol})$ in anhydrous dimethylformamide $(40 \mathrm{~mL})$ was stirred for 10 hours at $110{ }^{\circ} \mathrm{C}$. After this time, the solution was cooled and the insoluble salts were removed by filtration. The solvent was then evaporated under reduced pressure and the residue was dissolved in deionised water $(200 \mathrm{~mL})$ and acidified with concentrated $\mathrm{HCl}(3 \mathrm{~mL})$, to initiate precipitation. The product was removed by filtration, washed with water $(3 \times 40 \mathrm{~mL})$ and dried to give a brown solid. This was recrystallised from hot ethanol to afford $\mathbf{L} 1$ as brown needles (3 g, yield 51.3 \%). m.p. 221-223 ${ }^{\circ} \mathrm{C}$. $\mathrm{C}_{6} \mathrm{H}_{5} \mathrm{~N}_{5}$ (147.14): calcd. C 48.98, $\mathrm{H} 3.42, \mathrm{~N} 47.60$; found C 48.97, $\mathrm{H} 3.44, \mathrm{~N} 47.61 .{ }^{1} \mathrm{H} \mathrm{NMR}\left(\mathrm{CD}_{3} \mathrm{OD}\right): \delta=8.76(\mathrm{~d}, 1 \mathrm{H}, J=7.9 \mathrm{~Hz}$, pyr-H), 8.25 (d, $1 \mathrm{H}, J=7.9 \mathrm{~Hz}$, pyr-H), 8.03 (t, $1 \mathrm{H}, J=7.9 \mathrm{~Hz}$, pyr-H), 7.56 (t, $1 \mathrm{H}, J=7.9 \mathrm{~Hz}$, pyr-H), 3.9 (s, $1 \mathrm{H}$, tet-H) ppm. ${ }^{13} \mathrm{C} \mathrm{NMR}\left(\mathrm{CD}_{3} \mathrm{OD}\right): \delta=154.9\left(\mathrm{CN}_{4}\right), 150.1,143.7,138.3,126.2$, 122.7 ppm. ESI-HRMS: calcd for $\mathrm{C}_{6} \mathrm{H}_{5} \mathrm{~N}_{5}[\mathrm{M}]^{+}$147.054, found 147.054.

Synthesis of 2-(6',-bromoalkyl-(1-tetrazol-5-yl)pyridine (L2) and 2-(6"'-bromoalkyl-(2-tetrazol-5yl)pyridine (L3)

To $\mathbf{L 1}$ (1 g, $6.8 \mathrm{mmol}$ ) dissolved in either acetonitrile or 2-butanone (30 $\mathrm{mL}$ ) was added potassium carbonate $(9.38 \mathrm{~g}, 68 \mathrm{mmol})$. The resulting solution was refluxed for 30 minutes and to the hot solution was added 1,6-dibromohexane $(4.97 \mathrm{~g}, 24 \mathrm{mmol})$. The reaction mixture was then stirred at reflux temperature for a further $24 \mathrm{~h}$. After cooling, the solvent was removed under reduced pressure to afford an oil, which was purified by column chromatography on silica gel (initially at a ratio of petroleum ether : ethyl acetate $80: 20$, followed by the ratio of $60: 40$ ). This gave the products $\mathbf{L} 2$ and $\mathbf{L} 3$.

L2: Waxy white solid (0.55 g, yield $26 \%$ ). m.p. $39-41{ }^{\circ} \mathrm{C} . \mathrm{C}_{12} \mathrm{H}_{16} \mathrm{~N}_{5} \mathrm{Br}$ (310.19): calcd. C 46.46, $\mathrm{H}$ 5.20, N 22.58; found C 46.50, $\mathrm{H} 5.17, \mathrm{~N} 22.62 .{ }^{1} \mathrm{H}$ NMR $\left(\mathrm{CDCl}_{3}\right): \delta=8.77(\mathrm{~d}, 1 \mathrm{H}, J=7.5 \mathrm{~Hz}$, pyr- 
H), $8.37(\mathrm{~d}, 1 \mathrm{H}, J=7.5 \mathrm{~Hz}$, pyr-H), 7.96 (t, $1 \mathrm{H}, J=7.5 \mathrm{~Hz}$, pyr-H), 7.52 (t, $1 \mathrm{H}, J=7.5 \mathrm{~Hz}$, pyr$\mathrm{H}), 5.00\left(\mathrm{t}, 2 \mathrm{H}, J=6.9 \mathrm{~Hz}, \mathrm{CH}_{2} \mathrm{~N}\right), 3.42\left(\mathrm{t}, 2 \mathrm{H}, J=6.9 \mathrm{~Hz}, \mathrm{CH}_{2} \mathrm{Br}\right), 2.02(\mathrm{q}, 2 \mathrm{H}, J=7.1 \mathrm{~Hz}$, $\left.\mathrm{CH}_{2}\right), 1.87\left(\mathrm{~m}, 2 \mathrm{H}, \mathrm{CH}_{2}\right), 1.48\left(\mathrm{~m}, 4 \mathrm{H}, \mathrm{CH}_{2}\right) \mathrm{ppm} .{ }^{13} \mathrm{C} \mathrm{NMR}\left(\mathrm{CDCl}_{3}\right): \delta=151.4\left(\mathrm{CN}_{4}\right), 149.3$, 144.6, 137.1, 125.1, 124.2, $49.2\left(\mathrm{CH}_{2} \mathrm{~N}\right), 33.5\left(\mathrm{CH}_{2} \mathrm{Br}\right), 32.3$, 32.1, 29.4, 27.2 ppm. ESI-HRMS: calcd for $\mathrm{C}_{12} \mathrm{H}_{17} \mathrm{BrN}_{5}[\mathrm{M}+1]^{+} 310.067$, found 310.068 .

L3: Waxy white solid (0.35 g, yield $17 \%$ ). m.p. $36-38{ }^{\circ} \mathrm{C} . \mathrm{C}_{12} \mathrm{H}_{16} \mathrm{~N}_{5} \mathrm{Br}$ (310.19): calcd. C 46.46, $\mathrm{H}$ 5.20, N 22.58; found C 46.44, $\mathrm{H} 5.17, \mathrm{~N} 22.63 .{ }^{1} \mathrm{H} \mathrm{NMR}\left(\mathrm{CDCl}_{3}\right): \delta=8.80(\mathrm{~d}, 1 \mathrm{H}, J=7.7 \mathrm{~Hz}$, pyrH), $8.27(\mathrm{~d}, 1 \mathrm{H}, J=7.7 \mathrm{~Hz}$, pyr-H), 7.90 (t, $1 \mathrm{H}, J=7.7 \mathrm{~Hz}$, pyr-H), 7.43 (t, $1 \mathrm{H}, J=7.7 \mathrm{~Hz}$, pyr$\mathrm{H}), 4.73\left(\mathrm{t}, 2 \mathrm{H}, J=6.8 \mathrm{~Hz}, \mathrm{CH}_{2} \mathrm{~N}\right), 3.39\left(\mathrm{t}, 2 \mathrm{H}, J=6.8 \mathrm{~Hz}, \mathrm{CH}_{2} \mathrm{Br}\right), 2.13(\mathrm{q}, 2 \mathrm{H}, J=6.8 \mathrm{~Hz}$, $\left.\mathrm{CH}_{2}\right), 1.83\left(\mathrm{~m}, 2 \mathrm{H}, \mathrm{CH}_{2}\right), 1.51\left(\mathrm{~m}, 4 \mathrm{H}, \mathrm{CH}_{2}\right) \mathrm{ppm} .{ }^{13} \mathrm{C} \mathrm{NMR}\left(\mathrm{CDCl}_{3}\right): \delta=164.7\left(\mathrm{CN}_{4}\right), 150.2$, 146.7, 137.1, 124.8, 122.3, $53.2\left(\mathrm{CH}_{2} \mathrm{~N}\right), 33.4\left(\mathrm{CH}_{2} \mathrm{Br}\right), 32.4,32.2$, 29.0, 27.3 ppm. ESI-HRMS: calcd for $\mathrm{C}_{12} \mathrm{H}_{17} \mathrm{BrN}_{5}[\mathrm{M}+1]^{+} 310.067$, found 310.066 .

General coordination reactions (1-6)

The appropriate tetrazole ligand, $\mathbf{L} 2$ or $\mathbf{L 3}(0.20 \mathrm{~g}, 1.36 \mathrm{mmol})$, was dissolved in methanol (30 $\mathrm{mL})$ and was added to a solution of the appropriate metal salt $(1.36 \mathrm{mmol})$ in methanol $(25 \mathrm{~mL})$. The resulting strongly-coloured solution was then heated to reflux for $2 \mathrm{~h}$ before being allowed to stand at room temperature for several days.

\section{$\left[\mathrm{Cu}(\mathrm{L} 2) \mathrm{Cl}_{2}\right]_{2}(\mathbf{1})$}

Dark green crystals (0.137 g, yield $49 \%$ ). $\mathrm{C}_{24} \mathrm{H}_{32} \mathrm{Br}_{2} \mathrm{Cl}_{4} \mathrm{Cu}_{2} \mathrm{~N}_{10}$ (889.29): calcd. C 32.41, H 3.63, N 15.75; found C 32.52, H 3.71, N 15.73. IR (KBr): $v=2923,2852,1648,1610,1482,1256,1167$, $1139,1019,803,723 \mathrm{~cm}^{-1} . \lambda_{\max }\left(\mathrm{CH}_{3} \mathrm{CN}\right) 832 \mathrm{~nm}, \varepsilon=93 \mathrm{M}^{-1} \mathrm{~cm}^{-1}$. Magnetic moment: 2.6 B.M.

\section{$\left[\mathrm{Cu}(\mathrm{L} 3) \mathrm{Cl}_{2}\right]_{2}(\mathbf{2})$}

Dark green crystals (0.14 g, yield 50\%). $\mathrm{C}_{24} \mathrm{H}_{32} \mathrm{Br}_{2} \mathrm{Cl}_{4} \mathrm{Cu}_{2} \mathrm{~N}_{10}$ (889.29): calcd. C 32.41, H 3.63, $\mathrm{N}$ 15.75; found C 32.42, H 3.51, N 15.78. IR (KBr): v = 2923, 2856, 1648, 1610, 1483, 1278, 1165 , $1019,803,721 \mathrm{~cm}^{-1} . \lambda_{\max }\left(\mathrm{CH}_{3} \mathrm{CN}\right) 812 \mathrm{~nm}, \varepsilon=55 \mathrm{M}^{-1} \mathrm{~cm}^{-1}$. Magnetic moment: 3.2 B.M.

$\mathrm{Co}(\mathrm{L} 2)_{2}(\mathrm{NCS})_{2}(\mathbf{3})$ 
Rust coloured crystals (0.130 g, yield 26\%). $\mathrm{C}_{26} \mathrm{H}_{32} \mathrm{Br}_{2} \mathrm{CoN}_{12} \mathrm{~S}_{2}$ (795.48): calcd. C 39.26, H 4.05, N 21.13; found C 39.31, H 4.09, N 21.18. IR (KBr): $v=2933,2861,2075,1648,1473,1368,1247$, 1159, 1105, 1047, 795, $728 \mathrm{~cm}^{-1} . \lambda_{\max }\left(\mathrm{CH}_{3} \mathrm{CN}\right) 512 \mathrm{~nm}, \varepsilon=37 \mathrm{M}^{-1} \mathrm{~cm}^{-1}$. Magnetic moment: 4.5 B.M.

$\mathrm{Co}(\mathrm{L} 3)_{2}(\mathrm{NCS})_{2}(4)$

Green crystals (0.146 g, yield 29\%). $\mathrm{C}_{26} \mathrm{H}_{32} \mathrm{Br}_{2} \mathrm{CoN}_{12} \mathrm{~S}_{2}$ (795.48): calcd. C 39.26, H 4.05, N 21.13; found C 39.65, H 4.19, N 20.86. IR (KBr): $v=2928,2858,2075,1654,1474,1368,1247,1159$, $1105,1047,796,728 \mathrm{~cm}^{-1} . \lambda_{\max }\left(\mathrm{CH}_{3} \mathrm{CN}\right) 512 \mathrm{~nm}, \varepsilon=45 \mathrm{M}^{-1} \mathrm{~cm}^{-1}$. Magnetic moment: 3.65 B.M.

$\left[\mathrm{Fe}(\mathrm{L} 2)_{2}\left(\mathrm{H}_{2} \mathrm{O}\right)_{2}\right]\left(\mathrm{ClO}_{4}\right)_{2}(\mathbf{5})$

Yellow crystals $(0.09$ g, yield $16 \%) . \mathrm{C}_{24} \mathrm{H}_{36} \mathrm{Br}_{2} \mathrm{Cl}_{2} \mathrm{FeN}_{10} \mathrm{O}_{10}$ (911.16): calcd. C 31.64, H 3.98, N 15.37; found C 31.62, H 3.91, N 15.41. IR (KBr): $v=3407,2924,2852,1637,1478,1379,1250$, $1143,1112,798,727 \mathrm{~cm}^{-1} . \lambda_{\max }\left(\mathrm{CH}_{3} \mathrm{CN}\right) 364 \mathrm{~nm}, \varepsilon=1718 \mathrm{M}^{-1} \mathrm{~cm}^{-1}$. Magnetic moment: 4.7 B.M.

$\left[\mathrm{Fe}(\mathrm{L} 3)_{2}\left(\mathrm{H}_{2} \mathrm{O}\right)_{2}\right]\left(\mathrm{ClO}_{4}\right)_{2}(\mathbf{6})$

Yellow solid (0.11 g, yield 20\%). $\mathrm{C}_{24} \mathrm{H}_{36} \mathrm{Br}_{2} \mathrm{Cl}_{2} \mathrm{FeN}_{10} \mathrm{O}_{10}$ (911.16): calcd. C 31.64, H 3.98, N 15.37; found C 31.59, H 3.98, N 15.48. IR (KBr): $v=3410,2942,2862,1638,1451,1384,1145,1117$, 1089, $731 \mathrm{~cm}^{-1} . \lambda_{\max }\left(\mathrm{CH}_{3} \mathrm{CN}\right) 348 \mathrm{~nm}, \varepsilon=219 \mathrm{M}^{-1} \mathrm{~cm}^{-1}$. Magnetic moment: 5.0 B.M. To date, we have not been able to obtain crystals of $\mathbf{6}$ suitable for X-ray diffraction analysis.

\section{Crystallography}

X-ray diffraction data were collected on a Bruker APEX-II CCD diffractometer using graphitemonochromated Mo-K $\alpha$ radiation $(\lambda=0.7107 \AA$ ). In each case, a multi-scan correction was applied and the structures were refined against $F^{2}$ using all reflections. ${ }^{23}$ All non-H atoms were refined with anisotropic atomic displacement parameters and $\mathrm{H}$ atoms were placed at calculated positions and refined using a riding model. One of the hexyl chains in 2 is disordered, and the terminal $\mathrm{CH}_{2} \mathrm{Br}$ unit was refined over three orientations with site occupancies of $0.40,0.40$ and 0.20 . Similarity restraints were applied to the bond distances and to the displacement parameters. For $\mathbf{3}$, one of the $\mathrm{Br}$ atoms appears to be disordered and was included in two positions with refined site occupancies 0.81(1):0.19(1). Corresponding disorder of the neighbouring $\mathrm{CH}_{2}$ group could not be resolved, so 
one of the Br positions lies ca $2.3 \AA$ from the $\mathrm{CH}_{2}$ group. Comparable results were obtained from full data collections for two crystals within the batch. In $\mathbf{4}$, both independent bromohexyl chains are modelled as disordered over two orientations, one with site occupancies 0.50:0.50 and one with 0.70:0.30. Similarity restraints were applied to the bond distances and to the displacement parameters. In 5, the bromohexyl chain is modelled over two orientations with site occupancies 0.50:0.50, and the perchlorate anion is also modelled as disordered. The $\mathrm{H}$ atoms of the coordinated water molecules were visible in difference Fourier maps and their positions were refined with restrained $\mathrm{O}-\mathrm{H}$ distances.

\section{Conclusions}

The X-ray structures of several M(II) complexes of 2-(2H-tetrazol-5-yl)pyridine derivatives, containing a 6-bromohexyl pendant arm at either the 1-N (L2) or 2-N (L3) position of the tetrazole ring, have been studied. In all cases, the 5-(2-pyridyl)tetrazole ligand coordinates in a bidentate fashion through the pyridine nitrogen atom and the $1-N$ nitrogen of the tetrazole ring to form a fivemembered chelate ring with the metal ion. The coordination geometries in the two $\mathrm{Cu}$ (II) complexes ( $\mathbf{1}$ and $\mathbf{2}$ ) are slightly distorted square-pyramidal, due mainly to the formation of a dimeric $\mathrm{Cu}_{2} \mathrm{Cl}_{2}$ core. The coordination geometry at the metal centres in the other three structures $(\mathbf{3}$, 4 and 5) can be described as slightly distorted octahedral, with two 5-(2-pyridyl)tetrazole ligands occupying the equatorial plane in all cases. The axial positions are occupied by the two thiocyanate anions in the $\mathrm{Co}$ (II) complexes, while they are occupied by two water molecules in the case of the $\mathrm{Fe}(\mathrm{II})$ complex. The biological studies of these complexes and complexes involving other first row transition metal ions will be published in a separate paper. ${ }^{17}$

\section{Acknowledgments}

JG thanks the Postgraduate R\&D Skills programme (Technological Sector Research, Strand I) and IT Tallaght Dublin for financial assistance. US thanks NUIM for a John \& Pat Hume Fellowship. ADB is grateful to the Danish Natural Sciences Research Council and the Carlsberg Foundation for provision of the X-ray equipment.

\section{Appendix A. Supplementary data}

Electronic Supplementary Information (ESI) available: packing diagrams for the crystal structures of 1-5. CCDC <827225, 759312, 827226, 759313 and 759314> contains the supplementary 
crystallographic data for $\langle\mathbf{1 - 5}\rangle$. These data can be obtained free of charge via http://www.ccdc.cam.ac.uk/conts/retrieving.html, or from the Cambridge Crystallographic Data Centre, 12 Union Road, Cambridge CB2 1EZ, UK; fax: (+44) 1223-336-033; or e-mail: deposit@ccdc.cam.ac.uk.

\section{References}

1 R. N. Butler in Comprehensive Heterocyclic Chemistry II (Eds.: A. R. Katritzky, C. W. Rees, E. F. V. Scriven), Permagon, Oxford, 1996, 4, pp. 621.

2 R. J. Herr, Bioorg. \& Med. Chem. 10 (2002) 3379.

3 J. McGinley, A. Fleming, J. Incl. Phenom. Macrocycl. Chem. 61 (2008) 1.

4 G. Aromí, L. A. Barrios, O. Roubeau, P. Gamez, Coord. Chem. Rev. 255 (2011) 485.

5 (a) Z. P. Demko, K. B. Sharpless, J. Org. Chem. 66 (2001) 7945; (b) F. Himo, Z. P. Demko, L. Noodleman, K. B. Sharpless, J. Am. Chem. Soc. 125 (2003) 9983.

6 T. Mavromoustakos, A. Kolocouris, M. Zervou, P. Roumelioti, J. Matsoukas, R. Weisemann, J. Med. Chem. 42 (1999) 1714.

(a) R. A. Powers, B. K. Shoichet, J. Med. Chem. 45 (2002) 3222; (b) S. Y. Kang, S.-H. Lee, H. J. Seo, M. E. Jung, K. Ahn, J. Kim, J. Lee, Bioorg. Med. Chem. Lett. 18 (2008) 2385.

(a) G. C. G. Pais, X. Zhang, C. Marchand, N. Neamati, K. Cowansage, E. S. Svarovskaia, V. K. Pathak, Y. Tang, M. Nicklaus, Y. Pommier, T. R. Burke, Jr., J. Med. Chem. 45 (2002) 3184; (b) B. C. H. May, A. D. Abell, J. Chem. Soc., Perkin Trans. 1 (2002) 172.

(a) P. Lin, W. Clegg, R. W. Harrinton, R. A. Henderson, Dalton Trans. (2005) 2388; (b) W. Zhang, F. Zhao, T. Liu, M. Yuan, Z.-M. Wang, S. Gao, Inorg. Chem. 46 (2007) 2541; (c) S. Stagni, E. Orselli, A. Palazzi, L. De Cola, S. Zacchini, C. Femoni, M. Marcaccio, F. Paolucci, S. Zanarini, Inorg. Chem. 46 (2007) 9126; (d) G.-W. Yang, Q.-Y. Li, Y. Zhou, P. Sha, Y.-S. Ma, R.-X. Yuan, Inorg. Chem. Commun. 11 (2008) 723; (e) S. Stagni, S. Colella, A. Palazzi, G. Valenti, S. Zacchini, F. Paolucci, M. Marcaccio, R. Q. Albuquerque, L. De Cola, Inorg. Chem. 47 (2008) 10509; (f) A. Białońska, R. Bronisz, Tetrahedron 64 (2008) 9771; (g) B. Liu, Y.-C. Qiu, G. Peng, L. Ma, L.-M. Jin, J.-B. Cai, H. Deng, Inorg. Chem. Commun. 12 (2009) 1200; (h) Q.-Y. Li, G.-W. Yang, X.-Y. Tang, Y.-S. Ma, F. Zhou, W. Liu, J. Chen, H. Zhou, Inorg. Chem. Commun. 13 (2010) 254; (i) T. Hu, L. Liu, X. Lv, X. Chen, H. He, F. Dai, G. Zhang, D. Sun, Polyhedron 29 (2010) 296; (j) Y. Qiu, B. Liu, G. Peng, J. Cai, H. Deng, M. Zeller, Inorg. Chem. Commun. 13 (2010) 749; (k) Y. Huang, L.Z. Chen, R.-G. Xiong, X.-Z. You, Inorg. Chim. Acta 363 (2010) 2512; (1) J. M. Seco, M. de Araújo Farias, N. M. Bachs, A. B. Caballero, A. Salinas-Castillo, A. Rodríguez-Diéguez, 
Inorg. Chim. Acta 363 (2010) 3194; (m) B. K. Tripuramallu, R. Kishore, S. K. Das, Inorg. Chim. Acta 368 (2011) 132.

10 (a) X. He, C.-Z. Lu, D.-Q. Yuan, Inorg. Chem. 45 (2006) 5760; (b) H. Zhao, Z-R. Qu, H.-Y. Ye, R.-G. Xiong, Chem. Soc. Rev. 37 (2008) 84.

11 A. Fleming, J. Gaire, F. Kelleher, J. McGinley, V. McKee, Tetrahedron 67 (2011) 3260.

12 A. D. Bond, A. Fleming, J. Gaire, F. Kelleher, J. McGinley, V. McKee, Tetrahedron 65 (2009) 7942.

13 A. D. Bond, A. Fleming, F. Kelleher, J. McGinley, V. Prajapati, S. Skovsgaard, Tetrahedron 63 (2007) 6835.

14 A. D. Bond, A. Fleming, F. Kelleher, J. McGinley, V. Prajapati, Tetrahedron 62 (2006) 9577.

15 A. Fleming, F. Kelleher, M. F. Mahon, J. McGinley, V. Prajapati, Tetrahedron, 61 (2005) 7002 .

16 A. F. M. Fleming, F. Kelleher, M. F. Mahon, J. McGinley, K. C. Molloy, V. Prajapati, Acta Cryst. E60 (2004) 2388.

17 A. Fleming, J. Gaire, F. Kelleher, J. McGinley, U. Sheridan, unpublished results.

18 H. Gallardo, R. Magnago, A. J. Bortoluzzi, Liquid Cryst. 28 (2001) 1343.

19 P. A. Bethel, M. S. Hill, M. F. Mahon, K. C. Molloy, J. Chem. Soc., Perkin Trans. 1 (1999) 3507 .

20 R. N. Butler, A. F. M. Fleming, J. Heterocycl. Chem. 34 (1997) 691.

21 A. W. Addison, T. N. Rao, J. Reedijk, J. Van Rijn, G. C. Verschoor, J. Chem. Soc., Dalton Trans. (1984) 1349.

22 See, for example, (a) M. F. Mahon, J. McGinley, A. D. Rooney, J. M. D. Walsh, Inorg. Chim. Acta 362 (2009) 2353; (b) Y.-Y. Kou, J.-L. Tian, D.-D. Li, H. Liu, W. Gu, S.-P. Yan, J. Coord. Chem. 62 (2009) 2182; (c) S. Mandal, F. Lloret, R. Mukherjee, Inorg. Chim. Acta 362 (2009) 27; (d) D. H. Jeong, W. J. Park, J. H. Jeong, D. G. Churchill, H. Lee, Inorg. Chem. Commun. 11 (2008) 1170; (e) J. Astner, M. Weitzer, S. P. Foxon, S. Schindler, F. W. Heinemann, J. Mukherjee, R. Gupta, V. Mahadevan, R. Mukherjee, Inorg. Chim. Acta 361 (2008) 279; (f) A. Bernalte-García, A. M. Lozano-Vila, F. Luna-Giles, R. Pedrero-Marín, Polyhedron 25 (2006) 1399; (g) E. Tynan, P. Jensen, A. C. Lees, B. Moubaraki, K. S. Murray, P. E. Kruger, CrystEngComm. 7 (2005) 90.

G. M. Sheldrick, Acta Cryst. A64 (2008) 112. 